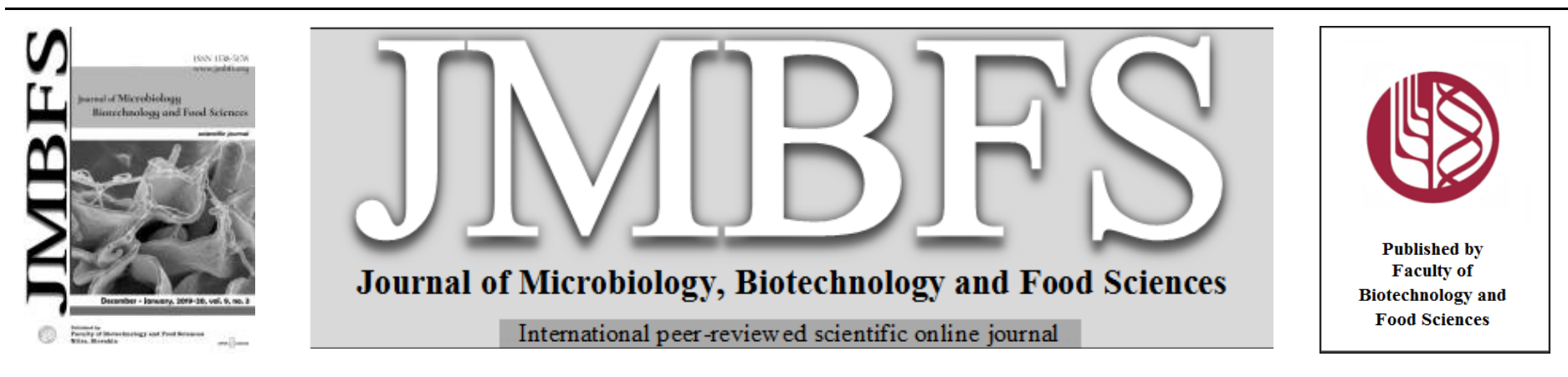

\title{
IN VITRO ACTIVITY OF SPICE EXTRACTS AGAINST ARCOBACTER SPP. AND INFLUENCE ON THEIR BIOFILM FORMATION
}

\author{
David Šilha*l, Barbora Hurdálkovál, Magdaléna Papajovál, Lucie Šilhovál
}

Address(es): Ing. David Šilha, Ph.D.

University of Pardubice, Faculty of Chemical Technology, Department of Biological and Biochemical Sciences, Studentská 573, 53210 Pardubice, Czech Republic, phone number: +420 466037765 .

*Corresponding author: David.Silha@upce.cz

doi: $10.15414 / j m b f s .2019 / 20.9 .3 .552-556$

\section{ARTICLE INFO}

Received 12. 2. 2019

Revised 30. 5. 2019

Accepted 5. 6. 2019

Published 1. 12. 2019

\section{Regular article}

open $\partial$ ACcess

\begin{abstract}
Several plants are considered to be new resources of substances that can be a potential alternative to combat particularly resistant microorganisms. Arcobacter spp. are dangerous bacteria with pathogenic potential and biofilm formation ability. The aim of this study was to evaluate the antimicrobial activity of six spice extracts against several Arcobacter-strains, including much less literally described strains as well. Among the evaluated spices, significant antibacterial activity of many samples was showed. The clove MetOH/DMSO (extraction in methanol/final dissolution in dimethylsulfoxide) extract had a MIC $\geq 20 \mathrm{mg} / \mathrm{mL}$, nutmeg MetOH/DMSO extract had MIC $10-20 \mathrm{mg} / \mathrm{mL}$, and the highest values were recorded in star anise extract (MIC $\geq 20 \mathrm{mg} / \mathrm{mL}$ ) after 24 hours of exposure. However, arcobacters were highly resistant to extracts from juniper, nutmeg and anise. Furthermore, the effect of extracts on biofilm formation was monitored using Christensen method. The tested extracts were found to have a dual effect on biofilm formation. The elimination of biofilm formation was observed, however also its stimulation, depending on the type of extract and the bacterial strain. The results indicate a particularly interesting antimicrobial effect of cloves and cinnamon extract (inhibition zones up to $30 \mathrm{~mm}$ ) against Arcobacter strains. The study shows a promising effect of tested extracts on biofilm formation for the first time.
\end{abstract}

Keywords: Arcobacter spp., biofilm, biofilm formation, natural extracts, biofilm inhibition

\section{INTRODUCTION}

Plants and their secondary metabolites are often used for their effects in the food industry or in healing. This is how spices, such as those known from ancient times, are used; not only for their aromatic ingredients but also for antimicrobial effects (Cowan, 1999). Many plants contain antimicrobial agents that inhibit the growth of food pathogens (Gyawali and Ibrahim, 2014; Mostafa et al., 2018; Tiwari et al., 2009). In general, gram-negative bacteria are less sensitive to antimicrobial agents than gram-positive, but this is not always the case (Tajkarimi et al., 2010).

The influence of natural extracts (eg. extracts from cinnamon, cloves, cilantro, thyme, star anise, garlic, onion, ginger, black pepper, etc.) on various bacteria has been observed in the past (Cervenka et al., 2006; Wang et al., 2012) and many have been found to have an antimicrobial effect. Microorganisms often occur in two forms, in the form of planktonic cells and microbial biofilms. The existence of microorganisms in a biofilm provides a wide range of benefits (resistance to antimicrobial agents, to drying, easier exchange of genetic material, nutrient transfer between cells, etc.). Biofilms are structured cell cultures adhered to the surface of a substrate and covered with extracellular matrix (Chmielewski and Frank, 2003; Flemming and Wingender, 2010). Biofilm formation itself is influenced by genetic and many other factors (eg. surface properties, $\mathrm{pH}$, amount of available nutrients, temperature, specificity of the bacterial strain, etc.) (Borucki et al., 2003; Donlan, 2002; Chmielewski and Frank, 2003).

Among the bacteria occurring in both planktonic and biofilm form, there are also bacteria of the Arcobacter genus (Collado and Figueras, 2011; Hrušková et al., 2013; Šilhová et al., 2015). Arcobacters are bacteria characterized not only by a broad distribution of occurrence, but also by resistance to various antimicrobial agents and influences) (Collado and Figueras, 2011; Kučerová et al., 2017; Shah et al., 2011; Šilha et al., 2013; Šilha et al., 2014; Šilha et al., 2015; Šilha et al., 2016; Šilha et al., 2017; Šilha et al., 2018). Arcobacter genus belongs to the family of Campylobacteraceae and includes both pathogenic (A. butzleri, A. cryaerophilus, A. skirrowii and A. thereius), as well as commonly occurring species (Perez-Cataluna et al., 2018; Van den Abeele et al., 2014).

The aim of this study was to evaluate the inhibitory effects of natural ethanol and methanol extracts (cloves, star anise, anise, cinnamon, juniper and nutmeg extract) dissolved in dimethylsulfoxide (DMSO) but also in ethanol against Arcobacter spp. There is a number of factors that can affect not only the growth of arcobacters but also their biofilm formation. The influence of natural extracts on the formation of Arcobacter biofilms is not well documented in the literature and this study includes new finding in this area. Among these are the antimicrobial effects of natural substances such as extracts from herbs and spices, essential oils, etc. Biofilm formation was observed by the Christensen method in selected Arcobacter strains, and the effect of selected natural extracts on biofilm formation was monitored. Furthermore, the tested extracts were found to have a dual effect on biofilm formation of Arcobacter spp. Elimination of biofilm formation was observed as well as its stimulation depending on the type of extract and the bacterial strain $(0.02-20 \mathrm{mg} / \mathrm{mL})$. The study also included significantly less known species of arcobacters (A. defluvii, A. thereius, A. lanthieri), which have only been described in recent years.

\section{MATERIAL AND METHODS}

\section{Plant materials and extraction procedure}

The selected dried spices Syzygium aromaticum (clove, bud, origin Madagascar), Illicium verum (star anise, fruit, origin - China), Myristica fragrans (nutmeg, seed, origin - Indonesia), Pimpinella anisum (anise, seed, origin Spain), Juniperus communis L. (juniper, fruit, origin - Macedonia), and Cinnamonum zeylanicum (cinnamon, bark, origin - Vietnam) were bought from local markets in the Czech Republic (distributor - Vitana a.s., Czech Republic). After crushing the plant parts, methanol p.a. (MetOH; Lach-Ner, Czech Republic) or ethanol p.a. (EtOH; Lach-Ner, Czech Republic) $(1: 2 \mathrm{w} / \mathrm{v})$ was used for the extraction of all spices. Extractions were conducted at room temperature for 4 days in the dark. After filtration, the filtrates were concentrated by evaporation to dryness. Dry extracts were dissolved in $20 \%$ dimethylsulfoxide (DMSO; Penta, Prague, Czech Republic) or $96 \%$ ethanol to a final concentration of $100 \mathrm{mg} / \mathrm{mL}$ (stock solution). The microbial sterility of the prepared extracts was verified before each testing. 


\section{Antimicrobial testing}

The microorganisms used in this study were as follows - A. butzleri CCUG 30484, A. butzleri UPa 2013/8 (strain isolated from waste water treatment), A cryaerophilus CCM 7050, A. cryaerophilus UPa 2013/13 (strain isolated from waste water treatment), A. butzleri LMG 10828, A. skirrowii LMG 6621, A defluvii LMG 25694, A. thereius LMG 24488, and A. lanthieri LMG 28517. Strains were purchased from the Czech Collection of Microorganisms (CCM Brno, Czech Republic), Culture Collection University of Göteborg (CCUG Göteborg, Sweden), Belgian Co-ordinated Collections of Microorganisms (LMG, Ghent, Belgium), and isolated at the University of Pardubice (UPa, Pardubice, Czech Republic). Cultures were grown on Mueller-Hinton agar (MHA, Oxoid Ltd., Basingstone, United Kingdom) before antimicrobial testing. Cells were harvested and suspended in physiological saline to a $0.5 \mathrm{McFarland}$ scale (ca 1.5 $\times 10^{8} \mathrm{CFU} / \mathrm{mL}$ ).

For antibacterial testing, the agar disc diffusion method was used. Plates containing Mueller-Hinton agar were spread with bacterial suspension adjusted to $1.5 \times 10^{8} \mathrm{CFU} / \mathrm{mL}$. Filter paper discs (6 $\mathrm{mm}$ diameter, Oxoid Ltd.) were placed onto inoculated agar surfaces and impregnated with $8 \mu \mathrm{l}$ of stock solution. Simultaneously, pure DMSO and EtOH were used as a negative control while ampicillin, ciprofloxacin, clindamycin, erythromycin, and tetracycline discs (Oxoid Ltd.) were used as a positive control. The plates were cultivated for $48 \mathrm{~h}$ at $30{ }^{\circ} \mathrm{C}$ under aerobic conditions. Inhibition zones were measured using a Bacmed 6iG2 automatized reader (Aspiag, Czech Republic). Experiments were performed in triplicates and the resulting activities $(\mathrm{mm})$ were expressed as a mean of inhibition zones $(\mathrm{mm})$ with standard deviation.

\section{Determination the survival of strains in extract presence}

The effect of various concentrations of selected MetOH/DMSO extracts (clove, star anise, nutmeg) on planktonic cells was monitored. Briefly, the twofold dilutions of extracts were prepared in BHI broth (Oxoid Ltd.) to obtain a final concentration ranging from 20 to $0.02 \mathrm{mg} / \mathrm{mL}$ in the wells after the addition of 20 $\mu \mathrm{l}$ of the freshly diluted tested cell culture containing $10^{8} \mathrm{CFU} / \mathrm{mL}$. Before and after incubation at $30{ }^{\circ} \mathrm{C}$ for $24 \mathrm{~h}$ under aerobic conditions, the absorbance was measured (TECAN Infinite M 200, Tecan Trading AG; Switzerland). At the same time, the culture after incubation was spread onto cultivation medium to determine whether the strain was culturable.

\section{Effect of natural extracts on biofilm formation}

The clove, star anise, and nutmeg MetOH/DMSO extracts were tested to evaluate their effect on biofilm formation. The effect of different concentrations (0.02-20 $\mathrm{mg} / \mathrm{mL}$ ) of the extracts on biofilm formation was monitored in 96-well polystyrene flat-bottomed microtiter plates (SPL Live Sciences Co., Ltd., Korea) as previously described (Christensen et al., 1985) with modifications. Briefly, the twofold dilutions of extracts were prepared in BHI broth to obtain a final concentration ranging from 20 to $0.02 \mathrm{mg} / \mathrm{mL}$ in the wells after the addition of 20 $\mu \mathrm{l}$ of the freshly diluted tested cell culture containing $10^{8} \mathrm{CFU} / \mathrm{mL}$. After incubation at $30{ }^{\circ} \mathrm{C}$ for $24 \mathrm{~h}$ under aerobic conditions, the microtiter plate was repeatedly washed (sterile distilled water) and dried. Fixation of the biofilm was performed with $2 \%$ sodium acetate $(15 \mathrm{~min})$, and attached cells were stained with $100 \mu \mathrm{l}$ of $1 \%$ crystal violet. After $15 \mathrm{~min}$ of staining, the plate was repeatedly washed and dried. Then the biofilm-associated crystal violet was solubilized with $96 \%$ ethanol, and the absorbance of the solution was measured in a new plate at 595 nm (TECAN Infinite M 200, Tecan Trading AG; Switzerland).

In addition, the effect of extract particles was monitored as an increasing in the final absorbance of the crystal violet after the staining process (Table 2). The experiments were performed as above, but without added bacterial cells. The effect of the extract components on the final absorbance value was eliminated by reducing the absorbance contribution of the extract (Fig 1-3).

There were 8 replicate wells in each experiment, experiments were independently repeated 3 times. The obtained values were statistically evaluated using Excel 2010 (Microsoft, USA) and Statistica 12 (StatSoft, USA). Extreme values were tested by the Dean-Dixon test, and any outlier values were excluded with $95 \%$ probability. The mean and standard deviation were determined from the remaining values. A possible source of mistakes was also considered, which is the effect of insufficient dye washing or the influence of the components of the extracts used, resulting in an increase in absorbance. Similarly, absorbance values that were too high compared to other measured values were excluded.

\section{RESULTS AND DISCUSSION}

\section{Antibacterial effect of natural extracts}

The effect of natural extracts and essential oils against Arcobacter spp. and Campylobacter spp. has been studied in several earlier studies (Cervenka et al., 2006; Irkin et al., 2011; Thanissery et al., 2014). However, most of the earlier studies only deal with the most well-known and most described species, $A$ butzleri and A. cryaerophilus. In our study, some of the recently described
Arcobacter species - A. defluvii, A. lanthieri - have also been included in the study, and also A. thereius, whose pathogenic potential has already been described (Van den Abeele et al., 2014).

The results of the antibacterial activity of the tested extracts are shown in Table 1. Each sample was extracted in two portions, ethanol and methanol. The extracts obtained were dissolved in DMSO (no inhibitory effect on the test bacteria) and ethanol (inhibitory effect of pure solvent 8-10 mm depending on the strain) at a final concentration of $100 \mathrm{mg} / \mathrm{mL}$. There was no significant difference between the antibacterial effects of ethanol and methanol extracts.

It is generally apparent from the results that the extracts finally dissolved in ethanol showed a logically higher antibacterial activity compared to those dissolved in DMSO. Very interesting antibacterial effects against Arcobacter spp. were recorded with cinnamon (inhibition zones: 7-16 $\mathrm{mm}$ - extracts in DMSO, and 10-32 $\mathrm{mm}-$ extracts in EtOH) and cloves extracts (inhibition zones: 8-18 $\mathrm{mm}$ - extracts in DMSO, and 13-21 $\mathrm{mm}$ - extracts in EtOH). The largest inhibition zones (up to $30 \mathrm{~mm}$, and $28.5 \mathrm{~mm}$ ) were found for A. cryaerophilus CCM 7050, and A. cryaerophilus UPa 2013/13 in case of EtOH/EtOH cinnamon extract.

On the other hand, the lowest antimicrobial activity against tested arcobacters was found for the juniper (inhibition zones: 6-7 $\mathrm{mm}$ - extracts in DMSO, and 10-14 mm - extracts in EtOH) and nutmeg extracts (inhibition zone: 6-8 mm extracts in DMSO, and 9-13.5 mm - extracts in EtOH). Anise extracts were slightly antibacterially active against most Arcobacter strains, but its highest inhibitory effect (inhibition zone up to $14 \mathrm{~mm}$ ) was observed against A. skirrovi LMG 6621. Similarly, the star anise extract was slightly antibacterial effective against most tested Arcobacter-strains. Its highest antimicrobial effect was against $A$. cryaerophilus CCM 7050, whereas the A. lanthieri LMG 28517 strain was comparatively resistant to this extract.

Among the traditional strains of the Arcobacter genus (A. butzleri, A cryaerophilus) there was a difference in susceptibility to the tested extracts. However, it was not possible to say whether the strains from collections were more or less susceptible than the strains isolated from the environment.

Overall, the strain A. lanthieri LMG 28517 was the most resistant of all the strains included in this study to the tested natural extracts. The highest zone of inhibition was found for extracts dissolved in DMSO, even in extracts which had a significant antibacterial effect on other Arcobacter-strains.

The antimicrobial activity of 8 plant essential oils against A. butzleri strains was previously tested (Irkin et al., 2011). Oil obtained from cloves was able to inhibit the growth of all arcobacters tested. The sensitivity of campylobacters has also been described for essential oils of rosemary, thyme, cloves and oranges (Thanissery et al., 2014). To the best of our knowledge, there is no information available in the literature on testing the antimicrobial effect of star anise and nutmeg against arcobacters. However, the antimicrobial activity of the star anise extract has been confirmed previously in case of other microorganisms (De et al., 2002). Similarly, for nutmeg extract, its antimicrobial efficacy has also been confirmed in previous studies (Gupta et al., 2013; Takikawa et al., 2002).

The previous study describes the effect of 17 methanol and chloroform extracts from some herbs and spices against three Arcobacter collection strains (Cervenka et al., 2006). Methanol extracts were rated as more antibacterially active, with the highest activity in rosemary, allspice, thyme, camomile, cinnamon, and others. According to our results, the inhibitory effect of cinnamon and clove was particularly high. However, due to the different testing procedure and the strains used, these results are not entirely comparable.

\section{Survival of planktonic cells in the presence of the natural extracts}

The viability of the strains after 24 hours of culture in the presence of selected $\mathrm{MetOH} / \mathrm{DMSO}$ extracts was evaluated by increasing the absorbance after cultivation and at the same time by cultivating on agar media. With the clove extract, almost all strains were found to survive at all concentrations (MIC $\geq 20$ $\mathrm{mg} / \mathrm{mL}$ ). However, the A. cryaerophilus UPa 2013/13 and A. skirrovii LMG 6621 strains did not survive the 24-h exposure at a concentration of $20 \mathrm{mg} / \mathrm{mL}$ (MIC $20 \mathrm{mg} / \mathrm{mL}$ ). The nutmeg extract was inhibitory to A. butzleri CCUG 30484 (MIC $20 \mathrm{mg} / \mathrm{mL}$ ), A. butzleri LMG 10828 (MIC $20 \mathrm{mg} / \mathrm{mL}$ ), A. cryaerophilus CCM 7050 (MIC $20 \mathrm{mg} / \mathrm{mL}$ ), A. skirrovii LMG 6621 (MIC $10 \mathrm{mg} / \mathrm{mL}$ ) and A. thereius LMG 24488 (MIC $10 \mathrm{mg} / \mathrm{mL}$ ). However, all of the strains tested survived the 24 $\mathrm{h}$ exposure at all the tested concentrations of the star anise extract.

\section{Biofilm formation in the natural extracts presence}

Due to biofilm resistance, the higher resistance of microorganisms in a biofilm is often discussed, leading to antimicrobial therapy failure. It is estimated that $65-80$ $\%$ of all resistant infections are caused by bacteria in the form of a biofilm (Dautle et al., 2003; Flemming and Wingender, 2010). Biofilm formation is a significant risk factor for the food industry, as well as other areas. The ability to produce a biofilm in Arcobacter spp. has already been described in the literature (Collado and Figueras, 2011), but this information is still missing for the species described in the last 10 years. According to our results, A. defluvii, A lanthieri and $A$. thereius are species capable of biofilm formation and according to our designation of the tested strains, they belong to the moderate producers of 
biofilms. Initial biofilm activity of the studied strains (at concentration of 0 $\mathrm{mg} / \mathrm{mL}$ ) was at different levels. The highest biofilm activity was observed for $A$. butzleri UPa 2013/8 (A=0.180-0.200). In contrast, A. butzleri CCUG 30484 and A. cryaerophilus UPa 2013/13 strains were rated as poor/nonbiofilm producers $(\mathrm{A}<0.120)$. Other Arcobacter strains were rated as moderate biofilm producers (A $=0.120-0.140)$. Furthermore, the biofilm activity of arcobacters in the presence of selected extracts of spices was studied.

A „cut-off score" $\left(\mathrm{A}_{\cos }\right)$ was determined to evaluate the biofilm production results. The value of $\mathrm{A}_{C O S-B H I}=0.112$ represents the final absorbance after coloring the remainder of the uninoculated BHI broth, and it is shown as a blank horizontal line in Fig 1-3. Furthermore, the $\mathrm{A}_{C O S-E X}$ for the individual tested extract concentrations was determined (Table 2) and this value was deducted from the final absorbance (A), as it represents the effect of the extract matrix and has no relation to biofilm formation. Bacterial strains whose $\mathrm{A} \leq \mathrm{A}_{C O S-B H}$ were considered biofilm-negative and strains with $\mathrm{A}>\mathrm{A}_{\text {COS-BHI }}$ were considered biofilm-positive.

Table 1 Antimicrobial effect of natural extracts of spices, used dilution solvent, and standard antibiotics (mean inhibition zones in mm, including disc $6 \mathrm{~mm}$ in diameter \pm standard deviation), $\mathrm{n}=3$

\begin{tabular}{|c|c|c|c|c|c|c|c|c|c|c|c|}
\hline & \multirow{2}{*}{$\begin{array}{l}\text { Extraction } \\
\text { solvent }\end{array}$} & \multirow{2}{*}{$\begin{array}{l}\text { Dilution } \\
\text { solvent }\end{array}$} & \multicolumn{3}{|c|}{ A. butzleri } & \multicolumn{2}{|c|}{ A. cryaerophilus } & \multirow{2}{*}{$\begin{array}{l}\text { A. skirrowii } \\
\text { LMG } 6621\end{array}$} & \multirow{2}{*}{$\begin{array}{l}\text { A. thereius } \\
\text { LMG } 24488\end{array}$} & \multirow{2}{*}{$\begin{array}{l}\text { A. lanthieri } \\
\text { LMG } 28517\end{array}$} & \multirow{2}{*}{$\begin{array}{l}\text { A. defluvii } \\
\text { LMG } 25694\end{array}$} \\
\hline & & & $\begin{array}{c}\text { CCUG } \\
30484\end{array}$ & $\begin{array}{c}\text { LMG } \\
10828\end{array}$ & UPa 2013/8 & CCM 7050 & $\begin{array}{c}\text { UPa } \\
2013 / 13\end{array}$ & & & & \\
\hline \multirow{4}{*}{ 芯 } & $\mathrm{EtOH}$ & DMSO & $15.5 \pm 0.5$ & $8 \pm 0.0$ & $9 \pm 0.5$ & $13 \pm 0.5$ & $12 \pm 0.5$ & $10 \pm 0.5$ & $10 \pm 0.5$ & $7.5 \pm 0.5$ & $7 \pm 0.0$ \\
\hline & $\mathrm{EtOH}$ & $\mathrm{EtOH}$ & $17.5 \pm 0.0$ & $12 \pm 0.0$ & $14.5 \pm 0.5$ & $30 \pm 1.5$ & $28.5 \pm 1.0$ & $28 \pm 1.5$ & $21.5 \pm 0.5$ & $13 \pm 0.5$ & $10.5 \pm 0.5$ \\
\hline & MetOH & DMSO & $14.5 \pm 0.0$ & $8 \pm 0.5$ & $9 \pm 0.5$ & $13 \pm 0.5$ & $10.5 \pm 0.5$ & $11 \pm 0.5$ & $11 \pm 0.5$ & $8 \pm 0.0$ & $7 \pm 0.0$ \\
\hline & MetOH & $\mathrm{EtOH}$ & $17.5 \pm 0.0$ & $12.5 \pm 0.5$ & $13.5 \pm 0.5$ & $23 \pm 0.5$ & $26.5 \pm 0.5$ & $23 \pm 1.0$ & $21.5 \pm 0.5$ & $14 \pm 0.5$ & $10.5 \pm 0.5$ \\
\hline \multirow{4}{*}{ 冚 } & $\mathrm{EtOH}$ & DMSO & $14.5 \pm 0.5$ & $12 \pm 0.0$ & $13.5 \pm 0.5$ & $14 \pm 0.0$ & $16 \pm 0.0$ & $12 \pm 0.5$ & $12 \pm 0.5$ & $8 \pm 0.0$ & $14.5 \pm 0.5$ \\
\hline & $\mathrm{EtOH}$ & EtOH & $14.5 \pm 0.0$ & $13.5 \pm 0.0$ & $14 \pm 0.0$ & 14.5 & $18 \pm 0.5$ & $20 \pm 0.0$ & $14.5 \pm 0.0$ & $14.5 \pm 0.5$ & $17.5 \pm 0.0$ \\
\hline & MetOH & DMSO & $16.0 \pm 0.0$ & $12.5 \pm 0.5$ & $14.5 \pm 0.5$ & $15 \pm 0.5$ & $18 \pm 0.0$ & $13 \pm 0.5$ & $10 \pm 0.0$ & $8 \pm 0.0$ & $17 \pm 0.5$ \\
\hline & MetOH & $\mathrm{EtOH}$ & $15.5 \pm 0.0$ & $15 \pm 0.0$ & $14.5 \pm 0.0$ & $17 \pm 0.0$ & $20 \pm 0.5$ & $20.5 \pm 0.0$ & $15 \pm 0.0$ & $11.5 \pm 0.5$ & $19 \pm 0.0$ \\
\hline \multirow{4}{*}{ 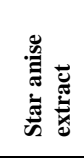 } & $\mathrm{EtOH}$ & DMSO & $8 \pm 0.5$ & $8 \pm 0.5$ & $8 \pm 0.5$ & $8 \pm 0.5$ & $9 \pm 0.5$ & $8 \pm 0.5$ & $8 \pm 0.0$ & $7 \pm 0.0$ & $8 \pm 0.5$ \\
\hline & $\mathrm{EtOH}$ & $\mathrm{EtOH}$ & $13 \pm 0.5$ & $13 \pm 0.5$ & $13.5 \pm 0.5$ & $16 \pm 0.5$ & $13 \pm 0.5$ & $13.5 \pm 0.5$ & $14 \pm 0.5$ & $12.5 \pm 0.5$ & $13 \pm 0.0$ \\
\hline & MetOH & DMSO & $8 \pm 0.5$ & $8 \pm 0.0$ & $8 \pm 0.5$ & $8 \pm 0.0$ & $8.5 \pm 0.5$ & $8 \pm 0.5$ & $8 \pm 0.5$ & $7.5 \pm 0.5$ & $8 \pm 0.5$ \\
\hline & MetOH & $\mathrm{EtOH}$ & $12.5 \pm 0.5$ & $13 \pm 0.5$ & $14 \pm 0.0$ & $15 \pm 0.5$ & $13 \pm 0.5$ & $13 \pm 0.5$ & $14 \pm 0.5$ & $12 \pm 0.5$ & $13 \pm 0.5$ \\
\hline \multirow{4}{*}{ 莺 } & $\mathrm{EtOH}$ & DMSO & $6.5 \pm 0.0$ & $6.5 \pm 0.5$ & $7 \pm 0.5$ & $7 \pm 0.0$ & $8 \pm 0.5$ & $8.5 \pm 0.5$ & $7 \pm 0.0$ & $7 \pm 0.5$ & $7 \pm 0.5$ \\
\hline & $\mathrm{EtOH}$ & EtOH & $11 \pm 0.5$ & $12 \pm 0.5$ & $13 \pm 0.0$ & $12.5 \pm 0.0$ & $10.5 \pm 0.5$ & $13.5 \pm 0.5$ & $13.5 \pm 0.0$ & $11 \pm 0.5$ & $11.5 \pm 0.0$ \\
\hline & $\mathrm{MetOH}$ & DMSO & n.i. & $6.5 \pm 0.5$ & $6.5 \pm 0.5$ & $7 \pm 0.5$ & $8 \pm 0.5$ & $8 \pm 0.5$ & $7 \pm 0.5$ & $7 \pm 0.5$ & $7 \pm 0.5$ \\
\hline & MetOH & $\mathrm{EtOH}$ & $11.5 \pm 0.5$ & $12 \pm 0.5$ & $13.5 \pm 0.5$ & $13 \pm 0.5$ & $11 \pm 0.5$ & $14 \pm 0.5$ & $13.5 \pm 0.5$ & $12 \pm 0.5$ & $11 \pm 0.5$ \\
\hline \multirow{4}{*}{ 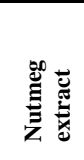 } & $\mathrm{EtOH}$ & DMSO & n.i. & n.i. & n.i. & n.i. & $8 \pm 0.5$ & $7 \pm 0.5$ & $7 \pm 0.5$ & n.i. & n.i. \\
\hline & $\mathrm{EtOH}$ & $\mathrm{EtOH}$ & $10.5 \pm 0.5$ & $10.5 \pm 0.5$ & $12.5 \pm 0.5$ & $10 \pm 0.5$ & $12 \pm 0.5$ & $12 \pm 0.5$ & $13 \pm 0.5$ & $10.5 \pm 0.5$ & $11.5 \pm 0.5$ \\
\hline & MetOH & DMSO & n.i. & n.i. & n.i. & n.i. & $7 \pm 0.0$ & $7 \pm 0.5$ & $7 \pm 0.5$ & n.i. & n.i. \\
\hline & MetOH & EtOH & $9 \pm 0.5$ & $12 \pm 0.5$ & $12 \pm 0.5$ & $10.5 \pm 0.5$ & $12 \pm 0.5$ & $12 \pm 0.5$ & $13.5 \pm 0.0$ & $12.5 \pm 0.0$ & $12.5 \pm 0.0$ \\
\hline \multirow{4}{*}{ 离芯 } & $\mathrm{EtOH}$ & DMSO & n.i. & n.i. & n.i. & n.i. & n.i. & $7.5 \pm 0.5$ & n.i. & n.i. & n.i. \\
\hline & $\mathrm{EtOH}$ & EtOH & $10.5 \pm 0.5$ & $10 \pm 0.5$ & $11 \pm 0.5$ & $13.5 \pm 0.0$ & $10.5 \pm 0.5$ & $13 \pm 0.5$ & $13.5 \pm 0.5$ & $10 \pm 0.5$ & $10.5 \pm 0.5$ \\
\hline & MetOH & DMSO & n.i. & n.i. & n.i. & n.i. & n.i. & $7 \pm 0.5$ & n.i. & n.i. & n.i. \\
\hline & MetOH & EtOH & $11.5 \pm 0.5$ & $12 \pm 0.5$ & $11 \pm 0.5$ & $12 \pm 0.5$ & $11.5 \pm 0.5$ & $12 \pm 0.5$ & $12.5 \pm 0.5$ & $10 \pm 0.5$ & $12 \pm 0.5$ \\
\hline EtOH & & & $8.5 \pm 0.5$ & $9.0 \pm 0.5$ & $9.0 \pm 0.5$ & $9.0 \pm 0.5$ & $9.5 \pm 0.5$ & $10.0 \pm 0.5$ & $9.5 \pm 0.5$ & $8.5 \pm 0.5$ & $9.5 \pm 0.5$ \\
\hline DMSO & & & n.i. & n.i. & n.i. & n.i. & n.i. & n.i. & n.i. & n.i. & n.i. \\
\hline $\begin{array}{l}\text { CIP } 5 \\
\mu \mathrm{g}\end{array}$ & & & $48.0 \pm 0.0$ & $56.0 \pm 0.0$ & $42.0 \pm 0.0$ & $32.0 \pm 0.0$ & $40.0 \pm 0.0$ & $42.0 \pm 0.0$ & $40.0 \pm 0.0$ & $44.0 \pm 0.0$ & $42.0 \pm 0.0$ \\
\hline $\begin{array}{l}\text { E } 15 \\
\mu \mathrm{g}\end{array}$ & & & $40.0 \pm 0.0$ & $31.0 \pm 0.0$ & $25.0 \pm 0.0$ & $25.0 \pm 0.0$ & $25.0 \pm 0.0$ & $25.0 \pm 0.0$ & $30.0 \pm 0.0$ & $25.0 \pm 0.0$ & $25.0 \pm 0.0$ \\
\hline $\begin{array}{l}\text { TE } 30 \\
\mu \mathrm{g}\end{array}$ & & & $29.0 \pm 0.0$ & $30.0 \pm 0.0$ & $25.0 \pm 0.0$ & $25.0 \pm 0.0$ & $27.0 \pm 0.0$ & $25.0 \pm 0.0$ & $44.0 \pm 0.0$ & $18.0 \pm 0.0$ & $25.0 \pm 0.0$ \\
\hline $\begin{array}{l}\text { AMP } \\
30 \mu g\end{array}$ & & & n.i. & n.i. & n.i. & n.i. & n.i. & n.i. & n.i. & n.i. & n.i. \\
\hline $\begin{array}{l}\text { DA } 2 \\
\mu \mathrm{g}\end{array}$ & & & n.i. & n.i. & n.i. & n.i. & n.i. & n.i. & n.i. & n.i. & n.i. \\
\hline
\end{tabular}

Legend: EtOH - ethanol, MetOH - methanol, DMSO - dimethylsulfoxide, AMP - ampicillin, CIP - ciprofloxacin, DA - clindamycin, E - erythromycin, TE tetracycline, n.i. - not inhibited

Table 2 Measured and calculated cut-off scores $(\mathrm{A}=595 \mathrm{~nm})$ of natural extracts

\begin{tabular}{|c|c|c|c|c|c|c|c|c|c|c|c|c|}
\hline $\begin{array}{l}\text { Concentration } \\
(\mathrm{mg} / \mathrm{mL})\end{array}$ & & 0.020 & 0.039 & 0.078 & 0.156 & 0.313 & 0.625 & 1.125 & 2.5 & 5 & 10 & 20 \\
\hline \multirow{2}{*}{$\begin{array}{l}\text { Clove } \\
\text { extract }\end{array}$} & $\mathrm{A}_{\mathrm{M}}$ & 0.126 & 0.130 & 0.124 & 0.131 & 0.131 & 0.129 & 0.133 & 0.136 & 0.151 & 0.139 & 0.176 \\
\hline & $\mathrm{A}_{\text {COS-EX }}$ & 0.014 & 0.018 & 0.012 & 0.019 & 0.019 & 0.017 & 0.021 & 0.024 & 0.029 & 0.027 & 0.064 \\
\hline \multirow{2}{*}{$\begin{array}{l}\text { Star anise } \\
\text { extract }\end{array}$} & $\mathrm{A}_{\mathrm{M}}$ & 0.113 & 0.116 & 0.117 & 0.128 & 0.129 & 0.125 & 0.122 & 0.120 & 0.123 & 0.134 & 0.213 \\
\hline & $\mathrm{A}_{\mathrm{COS}-\mathrm{EX}}$ & 0.001 & 0.004 & 0.005 & 0.017 & 0.018 & 0.013 & 0.011 & 0.008 & 0.011 & 0.022 & 0.101 \\
\hline \multirow{2}{*}{$\begin{array}{l}\text { Nutmeg } \\
\text { extract }\end{array}$} & $\mathrm{A}_{\mathrm{M}}$ & 0.124 & 0.129 & 0.130 & 0.130 & 0.131 & 0.136 & 0.132 & 0.134 & 0.132 & 0.141 & 0.267 \\
\hline & $\mathrm{A}_{\mathrm{COS}-\mathrm{EX}}$ & 0.012 & 0.017 & 0.018 & 0.019 & 0.020 & 0.024 & 0.020 & 0.022 & 0.020 & 0.029 & 0.155 \\
\hline
\end{tabular}

Legend: $\mathrm{A}_{\mathrm{M}}$ - median of measured absorbance of extracts in BHI broth, $\mathrm{A}_{\mathrm{COS}-\mathrm{EX}}$ - absorbance of extract (the increase in the value due to the content of the extract components)

To determine the effect of natural extracts on biofilm formation, methanol extracts from cloves, nutmeg and star anise were chosen, finally dissolved in DMSO (MetOH/DMSO). The dependence of biofilm formation in the presence of natural extracts is shown in Fig 1-3. The tested extracts were been found to have a dual effect on biofilm formation. On the one hand, an elimination of biofilm formation was observed, but also its stimulation, dependent on the type of extract and the given bacterial strain. 
Based on Fig 1-3, it can be stated that the tested natural extracts exhibited a similar effect on biofilm formation in all Arcobacter strains (similar trend), apart from some exceptions. Biofilm formation generally decreased with increasing concentration of the extract. A rapid decline in biofilm formation was observed at the highest extract concentration of $20 \mathrm{mg} / \mathrm{mL}$, for all tested strains and extracts. The biofilm formation of the studied arcobacters was thus successfully inhibited by higher concentrations of the extracts.

The clove extract was rated as the most effective in terms of the decline in biofilm formation of actually all Arcobacter spp. (Fig 1). Even at the lowest extract concentration $(0.02 \mathrm{mg} / \mathrm{mL})$, biofilm formation declined (the decline in absorbance from 0.189 to 0.127 ) rapidly in case of $A$. butzleri UPa 2013/8 strain In A. butzleri CCUG 30484, A. butzleri LMG 10828 and A. thereius LMG 24488 , complete biofilm inhibition occurred at this concentration. A. skirrovii LMG 6621 was evaluated as the resistant strain, with complete inhibition of biofilm formation at the concentration of $5 \mathrm{mg} / \mathrm{mL}$ of clove extract. The MBIC of clove extract was found even at the concentration of $20 \mathrm{mg} / \mathrm{mL}$ for the A. defluvii LMG 25694 strain. When comparing the strains of A. cryaerophilus, it was found that the collection strain was more biofilm-active and also forms biofilm in a medium with higher concentrations of the extract than the isolate of the same species.

Further, minimal biofilm inhibitory concentration (MBIC) determination and expression was performed, and the results are presented in Table 3. The MBIC is the minimal concentration of the natural compounds at which the biofilm formation was reduced to $\mathrm{A}_{595}<0.112$.

Table 3 Minimal biofilm inhibitory concentration (MBIC; $\mathrm{mg} / \mathrm{mL}$ ) of selected MetOH/DMSO natural extracts, $\mathrm{n}=3$

\begin{tabular}{|c|c|c|c|c|c|c|c|c|c|}
\hline & \multicolumn{3}{|c|}{ A. butzleri } & \multicolumn{2}{|c|}{ A.cryaerophilus } & \multirow{2}{*}{$\begin{array}{l}\text { A. skirrowii } \\
\text { LMG } 6621\end{array}$} & \multirow{2}{*}{$\begin{array}{l}\text { A.thereius } \\
\text { LMG } 24488\end{array}$} & \multirow{2}{*}{$\begin{array}{c}\text { A. lanthieri } \\
\text { LMG } 28517\end{array}$} & \multirow{2}{*}{$\begin{array}{c}\text { A. defluvii } \\
\text { LMG 25694 }\end{array}$} \\
\hline & $\begin{array}{c}\text { CCUG } \\
\mathbf{3 0 4 8 4}\end{array}$ & LMG 10828 & UPa 2013/8 & CCM 7050 & UPa 2013/13 & & & & \\
\hline $\begin{array}{l}\text { Clove } \\
\text { extract }\end{array}$ & 0.02 & 0.02 & 1.13 & 0.62 & 0.32 & 5.0 & 0.02 & 0.16 & 20.0 \\
\hline $\begin{array}{l}\text { Nutmeg } \\
\text { extract }\end{array}$ & 0.04 & 0.02 & 1.13 & 0.16 & 0.08 & 5.0 & 0.08 & 5.0 & 2.5 \\
\hline $\begin{array}{l}\text { Star anise } \\
\text { extract }\end{array}$ & 0.16 & 0.16 & 20.0 & 0.16 & 0.16 & 5.0 & 20.0 & 10.0 & 20.0 \\
\hline
\end{tabular}

Legend: MetOH/DMSO - extraction in methanol/final dissolution in dimethylsulfoxide

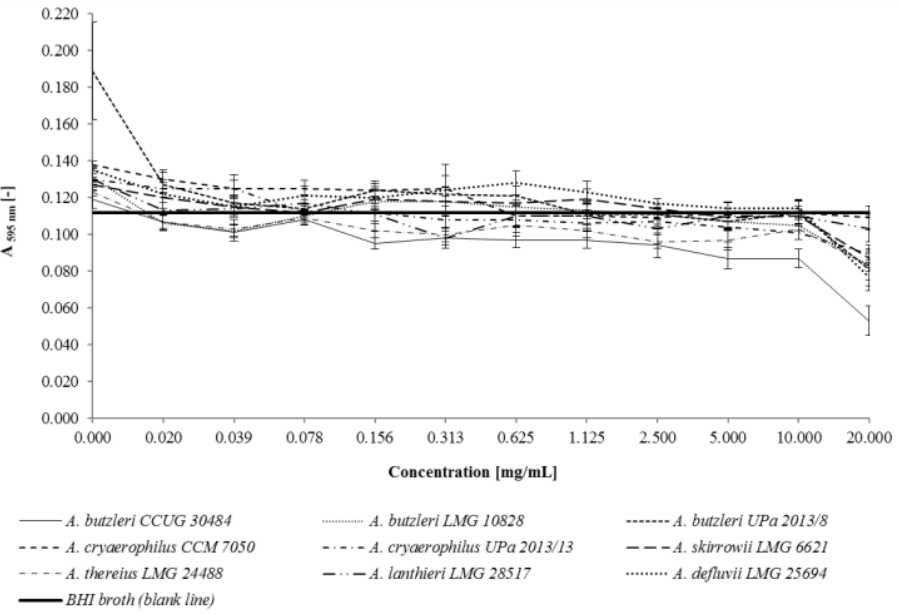

Figure 1 Effect of clove extract on biofilm formation of Arcobacter spp. (mean of measured data \pm standard deviation), $n=3$. The horizontal line represents the influence of BHI broth (values under horizontal line - biofilm-negative; values above line - biofilm-positive)

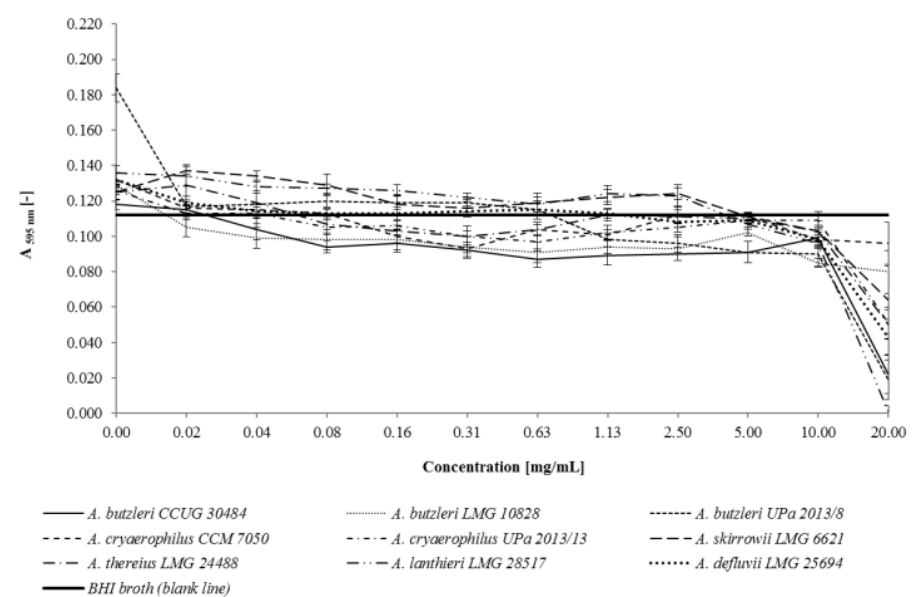

Figure 2 Effect of nutmeg extract on biofilm formation of Arcobacter spp. (mean of measured data \pm standard deviation), $n=3$. The horizontal line represents the influence of BHI broth (values under horizontal line - biofilm-negative; values above line - biofilm-positive)

The nutmeg extract eliminated the formation of a biofilm in A. butzleri LMG 10828 (Fig 2) at a low concentration of $0.02 \mathrm{mg} / \mathrm{mL}$, while in case of the collection strain (A. butzleri CCUG 30484) the MBIC was observed at a concentration of nutmeg extract of $0.04 \mathrm{mg} / \mathrm{mL}$. Overall, A. butzleri collection strains were evaluated as the easiest to suppress biofilm formation with this extract. Conversely, with A. skirrowii, at a concentration of $0.02 \mathrm{mg} / \mathrm{mL}$, the biofilm formation was increased from an initial value of 0.125 to 0.137 with a following gradual decrease and the MBIC was found to be $5 \mathrm{mg} / \mathrm{mL}$. A similar, yet milder effect was also observed in A. thereius.

Overall, star anise extract had the least antibacterial and antibiofilm effects against arcobacters. There was even a sharp increase in biofilm formation in the presence of lower concentrations of the extract, with A. lanthieri LMG 28517 (initial value of A without the effect of extract was 0.129; A increased to 0.174 at a concentration of $0.02 \mathrm{mg} / \mathrm{mL}$ ) and A. butzleri CCUG 30484 (initial value of A without the effect of extract was 0.120 ; A increased to 0.128 at a concentration of $0.02 \mathrm{mg} / \mathrm{mL}$ ). A. butzleri UPa 2013/8 retained a relatively high biofilm activity even at concentrations of star anise extract of about $1 \mathrm{mg} / \mathrm{mL}$ (Fig 3). In some strains, inhibition of biofilm formation was observed at an extract concentration of $0.156 \mathrm{mg} / \mathrm{mL}$, but in A. butzleri UPa 2013/8, A. thereius LMG 24488 and A defluvii LMG 25694, biofilm formation was completely inhibited at a concentration of $20 \mathrm{mg} / \mathrm{mL}$.

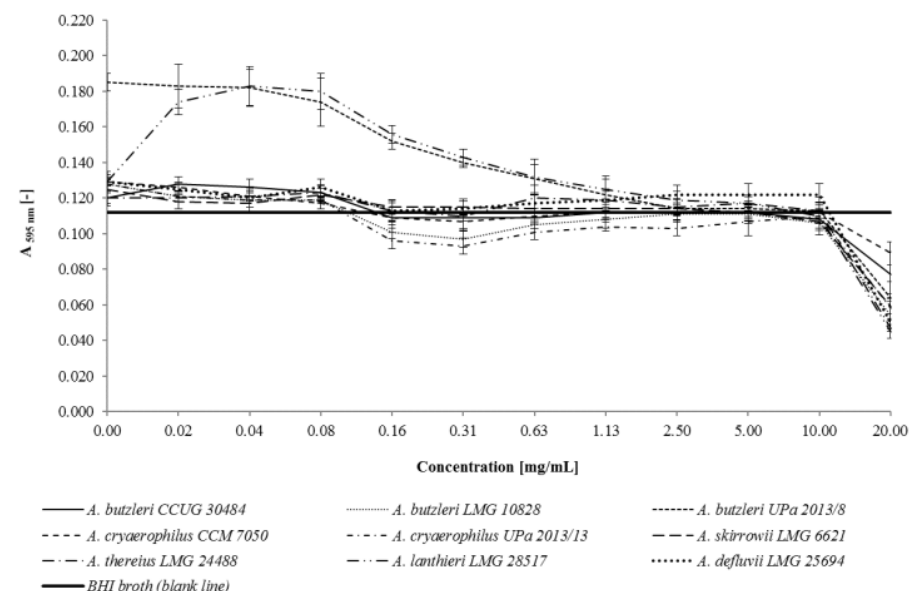

Figure 3 Effect of star anise extract on biofilm formation of Arcobacter spp (mean of measured data \pm standard deviation), $n=3$. The horizontal line represents the influence of BHI broth (values under horizontal line - biofilmnegative; values above line - biofilm-positive)

The influence of natural extracts on the formation of Arcobacter biofilms is not well documented in the literature. In our study, the effect of natural substances has been shown to be double effect. Some spices extracts (especially at lower concentration) stimulated the biofilm formation, on the other hand, other extracts eliminated biofilm formation. The stimulation of biofilm formation has been shown in particular in the case of star anise extract. The increase in biofilm formation at lower concentrations of star anise extract could be explained by the lower antimicrobial effect of this extract. Cells were prevented by increased biofilm formation at lower concentrations, however, this led to complete suppression of biofilm activity with increasing concentration. However, the effects of phenolic compounds on Pseudomonas aeruginosa biofilm have been described in the past. With these pure forms of phenolic compounds, the stimulation of biofilm formation was observed and inhibition only occurred at 
very high concentrations (Plyuta et al., 2013). Similarly, the inhibition of biofilm formation in Klebsiella pneumoniae was monitored with several natural substances (berberin, reserpin, chitosan, curcumin, eugenol and linoleic acid). In this work, the inhibition of biofilm activity and MBIC were determined in the range of $0.0156-0.25 \mathrm{mg} / \mathrm{mL}$ (Magesh et al., 2013). Weak antibiofilm activity was described for garlic extract with selected bacteria (Mohsenipour and Hassanshahian, 2015).

\section{CONCLUSION}

Natural substances isolated from plant matrices are currently required for their positive effects in the fight against microorganisms. We have presented inhibitory effect of clove, star anise, nutmeg, anise, juniper and cinnamon extracts against bacteria of the genus Arcobacter. This genus includes many species isolated from various environment, however, many studies deal with only a few of the best known species (A. butzleri and A. cryaerophilus). Moreover, our study includes other much less known species of arcobacters and thus bring new information to knowledge. The results show that clove and cinnamon extracts have the highest inhibitory effect from all extracts differently prepared and diluted in various solvents (DMSO, ethanol). Further, the present study demonstrated the effect of clove, nutmeg and star anise extracts on biofilm formation of nine Arcobacter strains. In general, the influence of natural extracts on the biofilm formation is not well documented in the literature and this study includes new finding in this area. To the best of our knowledge, this is the first study reporting the antibiofilm activity of the spice extracts against Arcobacter spp. The tested extracts were found to have a dual effect on biofilm formation of Arcobacter spp. On the one hand, the elimination of biofilm formation was observed (especially in higher concentration of tested extracts), but also it stimulation (e.g. in case of star anise extract), depending on the type of extract and the bacterial strain. The results of the study demonstrate that many spices inhibit the growth of potential pathogenic bacteria from the genus Arcobacter, either in planktonic or in biofilm phenotype, however, another testing is needed.

Acknowledgments: This work was supported by the Department of Biological and Biochemical Science, Faculty of Chemical Technology, University of Pardubice, Czech Republic [grants SGS_2018_004 and SGS_2019_007].

\section{REFERENCES}

BORUCKI, M.K., PEPPIN, J.D., WHITE, D., LOGE, F., CALL, D.R. 2003. Variation in biofilm formation among strains of Listeria monocytogenes. Appl Environ Microbiol, 69(12), 7336-7342. https://doi.org/10.1128/aem.69.12.7336$\underline{7342.2003}$

CERVENKA, L., PESKOVA, I., FOLTYNOVA, E., PEJCHALOVA, M., BROZKOVA, I., VYTRASOVA, J. 2006. Inhibitory effects of some spice and herb extracts against Arcobacter butzleri, A. cryaerophilus, and A. skirrowii. Curr Microbiol, 53(5), 435-439. https://doi.org/10.1007/s00284-006-0244-X

CHMIELEWSKI, R.A.N., FRANK, J.F. 2003. Biofilm formation and control in food processing and facilities. Compr Rev Food Sci Food Saf, 2(1), 22-32. https://doi.org/10.1111/j.1541-4337.2003.tb00012.x

CHRISTENSEN, G.D., SIMPSON, W.A., YOUNGER, J.J., BADDOUR, L.M. BARRETT, F.F., MELTON, D.M., BEACHEY, E.H. 1985. Adherence of coagulase-negative staphylococci to plastic tissue culture plates: a quantitative model for the adherence of staphylococci to medical devices. J Clin Microbiol, 22, 996-1006.

COLLADO, L., FIGUERAS, M.J. 2011. Taxonomy, Epidemiology, and Clinical Relevance of the Genus Arcobacter. Clin Microbiol Rev, 24(1), 174-192. https://doi.org/10.1128/cmr.00034-10

COWAN, M.M. 1999. Plant products as antimicrobial agents. Clin Microbiol Rev, 12(4), 564-582. https://doi.org/10.1128/cmr.12.4.564

DAUTLE, M.P., WILKINSON, T.R., GAUDERER, M.W.L. 2003. Isolation and identification of biofilm microorganisms from silicone gastrostomy devices. J Pediatr Surg, 38(2), 216-220. https://doi.org/10.1053/jpsu.2003.50046

DE, M., DE, A.K., SEN, P., BANERJEE, A.B. 2002. Antimicrobial properties of star anise (Illicium verum hook f). Phytother Res, 16(1), 94-95 https://doi.org/10.1002/ptr.989

DONLAN, R.M. 2002. Biofilms: Microbial life on surfaces. Emerg Infect Dis, 8(9), 881-890. https://doi.org/10.3201/eid0809.020063

FLEMMING, H.C., WINGENDER, J. 2010. The biofilm matrix. Nat Rev Microbiol, 8(9), 623-633. https://doi.org/10.1038/nrmicro2415

GUPTA, A.D., BANSAL, V.K., BABU, V., MAITHIL, M. 2013. Chemistry, antioxidant and antimicrobial potential of nutmeg (Myristica fragnans Houtt). J Gen Eng Biotech, 11(1), 25-31. https://doi.org/10.1016/j.jgeb.2012.12.001

GYAWALI, R., IBRAHIM, S.A. 2014. Natural products as antimicrobial agents. Food Control, 46, 412-429. https://doi.org/10.1016/i.foodcont.2014.05.047

HRUŠKOVÁ, L., MOŤKOVÁ, P., VYTŘASOVÁ, J. 2013. Multiplex polymerase chain reaction using ethidium monoazide and propidium monoazide for distinguishing viable and dead cells of arcobacters in biofilm. Can J Microbiol, 59(12), 797-802. https://doi.org/10.1139/cjm-2013-0635
IRKIN, R., ABAY, S., AYDIN, F. 2011. Inhibitory Effects of Some Plant Essential Oils Against Arcobacter butzleri and Potential for Rosemary Oil as a Natural Food Preservative. J Med Food, 14(3), 291-296. https://doi.org/10.1089/jmf.2010.0001

KUČEROVÁ, S., ŠILHA, D., VYTŘASOVÁ, J., ŠVECOVÁ, B. 2017. Survival of Arcobacter butzleri and Arcobacter cryaerophilus strains in the presence of sea buckthorn extracts. J Food Nutr Res, 56, 10-17.

MAGESH, H., KUMAR, A., ALAM, A., PRIYAM, SEKAR, U., SUMANTRAN, V.N., VAIDYANATHAN, R. 2013. Identification of natural compounds which inhibit biofilm formation in clinical isolates of Klebsiella pneumoniae. Indian J Exp Biol, 51, 764-772.

MOHSENIPOUR, Z., HASSANSHAHIAN, M. 2015. The Effects of Allium sativum Extracts on Biofilm Formation and Activities of Six Pathogenic Bacteria. Jundishapur J Microbiol, 8(8). https://doi.org/10.5812/jjm.18971v2

MOSTAFA, A.A., AAL-ASKAR, A.A., ALMAARY, K.S., DAWOUD, T.M. SHOLKAMY, E.N., BAKRI, M.M. 2018. Antimicrobial activity of some plant extracts against bacterial strains causing food poisoning diseases. Saudi J Biol Sci, 25(2), 361-366. https://doi.org/10.1016/j.sjbs.2017.02.004

PEREZ-CATALUNA, A., SALAS-MASSO, N., FIGUERAS, M.J. 2018 Arcobacter canalis sp nov., isolated from a water canal contaminated with urban

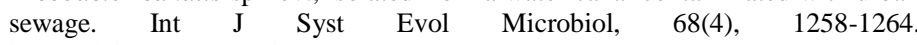
https://doi.org/10.1099/ijsem.0.002662

PLYUTA, V., ZAITSEVA, J., LOBAKOVA, E., ZAGOSKINA, N., KUZNETSOV, A., KHMEL, I. 2013. Effect of plant phenolic compounds on biofilm formation by Pseudomonas aeruginosa. Apmis, 121(11), 1073-1081. https://doi.org/10.1111/apm.12083

SHAH, A.H., SALEHA, A.A., ZUNITA, Z., MURUGAIYAH, M. 2011. Arcobacter - An emerging threat to animals and animal origin food products? Trends Food Sci Technol, 22(5), 225-236. https://doi.org/10.1016/j.tifs.2011.01.010

ŠILHA, D., HRUŠKOVÁ, L., BROŽKOVÁ, I., MOŤKOVÁ, P., VYTŘASOVÁ, J. 2014. Survival of selected bacteria from the genus Arcobacter on various metallic surfaces. J Food Nutr Res, 53, 217-223.

ŠILHA, D., PEJCHALOVÁ, M., ŠILHOVÁ, L. 2017. Susceptibility to 18 drugs and multidrug resistance of Arcobacter isolates from different sources within the

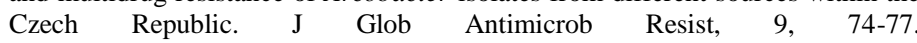
https://doi.org/10.1016/j.jgar.2017.01.006

ŠILHA, D., ŠILHOVÁ, L., VYTŘASOVÁ, J., BROŽKOVÁ, I., PEJCHALOVÁ, P. 2016. Survival of selected bacteria of Arcobacter genus in disinfectants and possibility of acquired secondary resistance to disinfectants. J

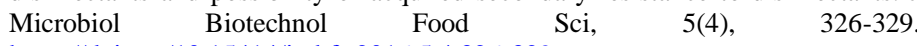
https://doi.org/10.15414/jmbfs.2016.5.4.326-329

ŠILHA, D., ŠILHOVÁ-HRUŠKOVÁ, L., VYTŘASOVÁ, J. 2015. Modified isolation method of Arcobacter spp. from different environmental and food samples. Folia Microbiol, 60, 515-521.

ŠILHA, D., VACKOVÁ, B., ŠILHOVÁ, L. 2018. Occurrence of virulenceassociated genes in Arcobacter butzleri and Arcobacter cryaerophilus isolates from foodstuff, water, and clinical samples within the Czech Republic. Folia Microbiol, 64(1), 25-31. https://doi.org/10.1007/s12223-018-0628-X

ŠILHA, D., VYTŘASOVÁ, J., BEŇOVÁ, B., MOŤKOVÁ, P. 2013. Effect of Selected Types of Beer on Bacteria of the Genus Arcobacter. Curr Microbiol, 66(4), 368-373. https://doi.org/10.1007/s00284-012-0272-7

ŠILHOVÁ, L., MOŤKOVÁ, P., ŠILHA, D., VYTŘASOVÁ, J. 2015. FISH

detection of Campylobacter and Arcobacter adhered to stainless steel coupons. J

Microbiol Biotechnol Food Sci, 4(4), 341-351.

https://doi.org/10.15414/jmbfs.2015.4.4.347-351

TAJKARIMI, M.M., IBRAHIM, S.A., CLIVER, D.O. 2010. Antimicrobial herb and spice compounds in food. Food Control, 21(9), 1199-1218. https://doi.org/10.1016/j.foodcont.2010.02.003

TAKIKAWA, A., ABE, K., YAMAMOTO, M., ISHIMARU, S., YASUI, M., OKUBO, Y., YOKOIGAWA, K. 2002. Antimicrobial activity of nutmeg against Escherichia coli O157. J Biosci Bioeng, 94(4), 315-320. https://doi.org/10.1263/jbb.94.315

THANISSERY, R., KATHARIOU, S., SMITH, D.P. 2014. Rosemary oil, clove oil, and a mix of thyme-orange essential oils inhibit Salmonella and Campylobacter in vitro. J Appl Poult Res, 23(2), 221-227. https://doi.org/10.3382/japr.2013-00888

TIWARI, B.K., VALDRAMIDIS, V.P., O'DONNELL, C.P. MUTHUKUMARAPPAN, K., BOURKE, P., CULLEN, P.J. 2009. Application of Natural Antimicrobials for Food Preservation. J Agric Food Chem, 57(14), 5987-6000. https://doi.org/10.1021/jf900668n

VAN DEN ABEELE, A.M., VOGELAERS, D., VAN HENDE, J., HOUF, K. 2014. Prevalence of Arcobacter Species among Humans, Belgium, 2008-2013. Emerg Infect Dis, 20(10), 1731-1734. https://doi.org/10.3201/eid2010.140433 WANG, Q., OU, Z.B., LEI, H.W., ZENG, X.H., YING, Y., BAI, W.D. 2012. Antimicrobial activities of a new formula of spice water extracts against foodborne bacteria. J Food Process Preserv, 36(4), 374-381. https://doi.org/10.1111/j.1745-4549.2012.00691.x 